Original scientific article

UDC: $614.3(497) " 17 "$

ID: 228298252

DOI 10.25106/AHM.2016.1012

\author{
Miloš Đorđević \\ History Department \\ Faculty of Philosophy, University of Niš \\ Ćirila i Metodija 2, 18000 Niš, Serbia \\ milos.djordjevic@filfak.ni.ac.rs
}

\title{
SANITARY POLICY OF HABSBURG MONARCHY AND ORGANIZATION OF PARAĆIN QUARANTINE IN $18^{\mathrm{TH}}$ CENTURY* $^{*}$
}

\begin{abstract}
After establishment of administration in newly acquired provinces at southeast of Europe, because of frequent plague epidemics Habsburg Monarchy formed a sanitary safety belt at the border with Ottoman Empire. This paper will describe measures taken at Paraćin quarantine that, in the period 1718-1739 used to be one of the busiest. Organization of the quarantine, procedures and instructions sent by Royal court commission were aimed at preventive actions to protect population health.
\end{abstract}

Key words: plague, 18th century, Habsburg Monarchy, quarantine, Ottoman Empire Non MeSH: Paraćin

Occurrence of plague was permanent threat to lives of population of Southeast Europe, especially in 18th century. Devastating disease that often took more lives than wars and their consequences arrived to territory of Habsburg Monarchy from Ottoman territories in the Balkans. One of key causes was regulation of trade between Ottoman and Habsburg subjects regulated by Peace treaty of Požarevac in 1718 , for after that ensued constant increase in volume of trade and number of people crossing border. The result of increased mobility of citizens of two empires was faster spreading of infections, and that compelled Vienna court to establish sanitary safety belt and apply different sanitary measures to diminish risks from plague. Emulating measures applied by sanitary commissions of Venice and France, regulations

\footnotetext{
* This paper resulted from research during the project Modernization of Western Balkans (rec. no. 177009) financed by the Ministry of education, science and technological development of Republic of Serbia.
} 
were imposed during the reign of Habsburg rulers Joseph I and Charles (Karl) VI and most important ones were defining establishing of sanitary safety belt at the border with Ottoman Empire. In that was a new direction of public policy was formed, reduced to certain aspects of public regulation of human lives. Although legislature that made foundation of policy for fighting communicable diseases was investigated and announced in Vienna, as was for instance Pest-Ordnung of October 1710, their application and efficiency was tested at the border, i.e. in quarantines that made first stop for travellers who crossed the border through merchant roads. [1 pp283, 2 p158, 3 p 479, 4 p98].

In order to eliminate biological hazard to its own population and secure border with Ottoman Empire, Habsburg Monarchy used both military and administrative apparatus in 18th century. Peacetime period marked new methods the state applied to discard risks of population mass die-off due to epidemics of the disease whose causes science of the time still did not recognize. Gradual adapting of epidemics defense mechanism during the century should have led to better prediction of levels of risk, aiming to bring sanitary measures in Monarchy through statistical estimations closer to mechanisms existing in other European countries. The issue of diseases was not something that concerned just Court sanitary service in the Monarchy, but the whole state apparatus since that threatened also political interests. One of the goals in New Acquisition lands that Monarchy tried to impose was increasing population density in regions deserted by war, through moving German population from western provinces and by attracting Christians from Ottoman Empire [5 p14]. For that reasons especially in border provinces were applied measures aimed to increase security of population regarding both domestic and foreign dangers, to control risk from epidemics and, finally, to reduce severity of eventual consequences.

Population of Kingdom of Serbia, a newly acquired province of Habsburg Monarchy (1718-1739), and that in border area under Ottoman rule was for many reasons most exposed to all epidemics of communicable diseases. As a border region, it hosted military crews (of regular Austrian army and Serbian people's militia at military border), and was transit area for merchants and travellers from all parts of both empires, and it meant first of all people from Constantinople that used to be focal point of almost all plague epidemics in Ottoman Empire so it became virtually endemic. Due to ignorance of preventive measures, such as parting living space of healthy and diseased. The plague at Balkans was almost permanently present to larger or smaller extent and it was taking away thousands of human lives. Possible endemic regions for plague were also northern Albania, and wider region of Sarajevo and Mostar, but plague at Balkans did not seized all these regions simultaneously [6 p939]. Through preventing forming of endemic regions, the Monarchy wanted to avoid continuance and intensity of the disease and eliminate a factor that was taking strength, energy and productivity from its population.

Epidemics of plague at Balkans in 18th century appeared from time to time, so there are actually several shorter and longer periods when they lasted. There are 
not many details on plague epidemics at the time when Paraćin quarantine existed, neither in sources nor in literature. Most data on epidemics in that time come from Venetian sources, more precisely from reports by individuals and notification by sanitary authorities of Venice of July 28 1719, and from report of Ardeal physician Chenot [6 p937, 7 p221]. On the death of many Austrian soldiers in Belgrade on August 22, 1719 reported Vincenzo Antonio Pedro, probably a member of Venetian sanitary service, while Carlo Ruzzini at his arrival to Constantinople on September 23, 1719 reported on plague that months earlier devastated that city [6 p939-941]. Also in that period Lady Wortly Montagu in his letters on travelling through Ottoman Empire recorded in Constantinople plague incidents that were spreading fast. These news were later received by sanitary authorities of several European countries [8 pp712, 9 p183, 10 p336]. With stronger or weaker intensity, plague was present in Prizren region in November 1722, and in Valjevo in 1734 [6 p941, 11 p16]. After a short period with no records on spreading of communicable diseases started a new Austro-Turkish war, and at that time plague appeared in Austrian army in 1738 and was transferred to Hungary and Timisoara Banat [7 p240].

The application of sanitary measures is usually attributed to the governor (Landshauptmann) of Upper Austria, Christoph Wilhelm Graf von Thürheim [12 p968], who in September 1719 issued an order to have applied necessary measures in the Monarchy to prevent spreading disease from Kingdom of Serbia, but also from Ardeal, Wallachia and Rijeka (Fiume). This act primarily demonstrates the urge of the state to establish control over internal epidemics risks, but also to separate periphery population from the rest of Monarchy in exceptional situations. Austrian authorities were taking seriously notes from Venetian Republic on epidemics, as confirmed by the fact that sanitary safety belt was established straight away in New Acquisition lands and that order was issued on better control of border with Ottoman Empire. That required all people crossing border to be examined and controlled in quarantines at main merchant roads, and to prevent illegal crossings of smugglers with a help of Serbian militia, regular army and district authorities. Cooperation between military and civil authorities is documented by establishing of permanent communication of commanders and officers of border garrisons of Austrian army with staff of quarantines, via two so-called post-officers. They were in charge of relaying letters and received monthly income of 50 forint and additional expenses from chamber income. These officers in exceptional situations had full authority to deliberate measures of sanitary policy at the border without prior consultations with Court war council or border garrison command [13]. Although newly acquired provinces had same legal status in the Habsburg Monarchy but with separate administrations, supreme authorities order that, if plague appeared in any of them, such province should be isolated by sanitary safety belt from the rest of the Monarchy [13].

Isolation of contaminated regions was different in urban and rural environments. In villages military authorities took all necessary measures to prevent further spreading of plague. People were forced to stay in their homes, and all social events 
were banned. Domestic animals, foremost poultry, dogs and cats, were killed for it was believed they are prime carriers of plague. In urban environments, city authorities organized quarantine on their own. To prevent infected persons from even entering city, at borders all travellers were given certificate on their health condition. If symptoms of disease, due to incubation period, appeared later, despite possession of certificate by border service such infected person was forbidden to enter city. For all diseased travellers there was a special house outside city where they could reside. Despite all precautions, cities were often seized by epidemics. To cut down human losses, city authorities separated infected from healthy persons. Corpses were put in coffins and buried deep into the ground, and all personal property of infected person was burned. As a preventive measure, citizens had to keep houses clean, and city took over treatment expenses for poorest citizens. On September 25, 1719 requested was closing of borders between Ardeal, Hungary, Timisoara Banat and imperial Wallachia, and break of any kind of communication between Monarchy and Ottoman Empire on Danube, Timok, Morava, Drina, on Sava towards Bosnia and in all imperial ports at the Adriatic [14 p77].

The quarantine of Paraćin was one of the most important for Austrian authorities, not just because it was situated at so called Imperial road, but also because of income that Head customs office received from customs tariffs [15 pp75]. While province was still ruled by the army, general Odwyer ordered in 1720 building of the quarantine, and he submitted to the Commission of New Acquisitions in Vienna project sketches and estimated costs of building [16 p56]. The notes that representa-

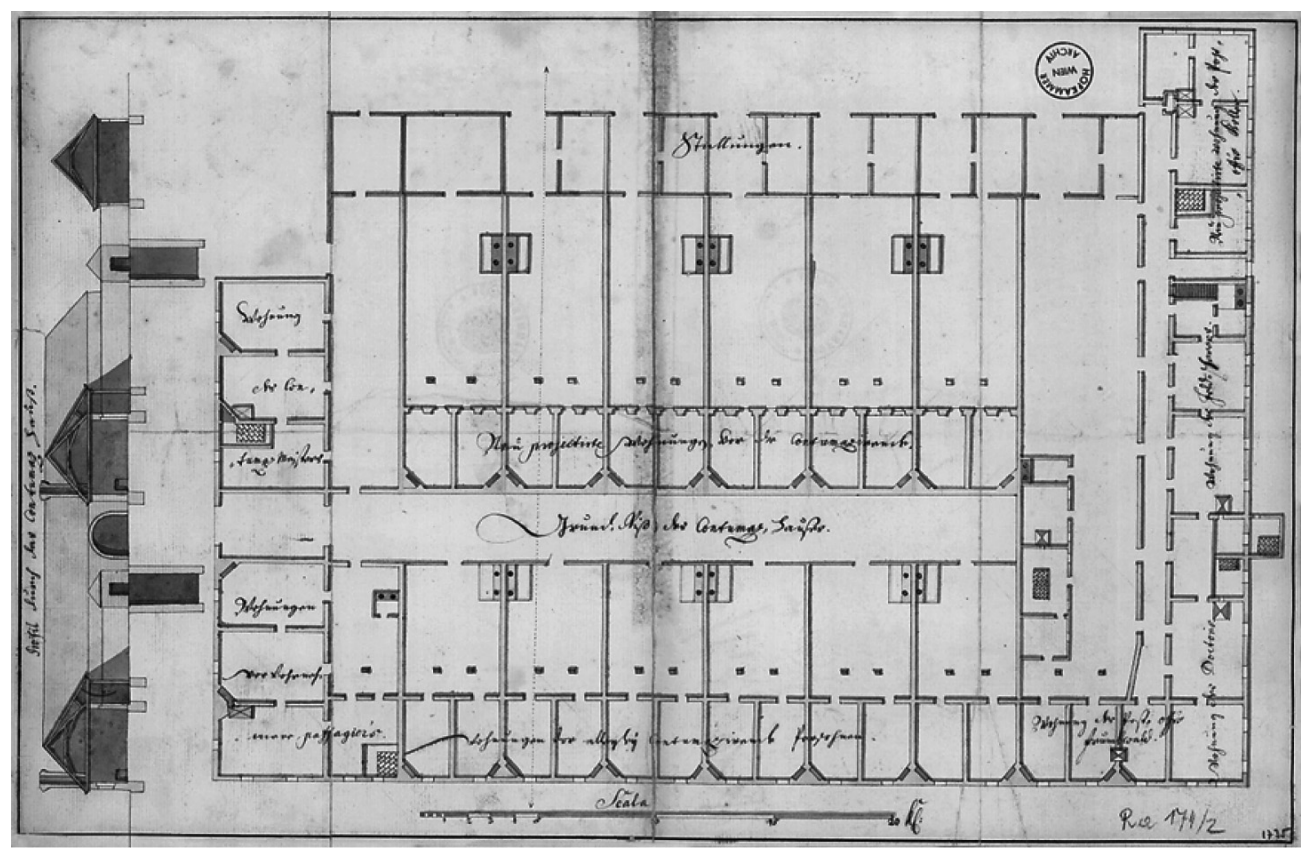

Fig. 1. Sketch of Paraćin quarantine (War archive, Vienna, 1735) [18] 
tives of Court sanitary commission wrote regarding Paraćin quarantine give impression that building was inadequate for number of people and quantity of goods that it should accommodate [17 pp32]. Forming of Belgrade administration, and Head customs office as one of its most important sectors, made it possible to renovate and enlarge all quarantines at the border with Ottoman Empire. Head chamber office in Serbia accepted obligation to pay building costs, while supervision was left to representatives of War council or commanders of Austrian troops situated close to the border. Large enterprises, such as building sanitary safety belt, required a lot of money, and in the Monarchy after exhausting wars it was hard to find. In this paper are presented project drawings for quarantines in Paracin and Prnjavor, and these projects were accomplished gradually during Austrian rule, so according to the report of financial control service of that administration, objects were fully completed just in 1736 [13].

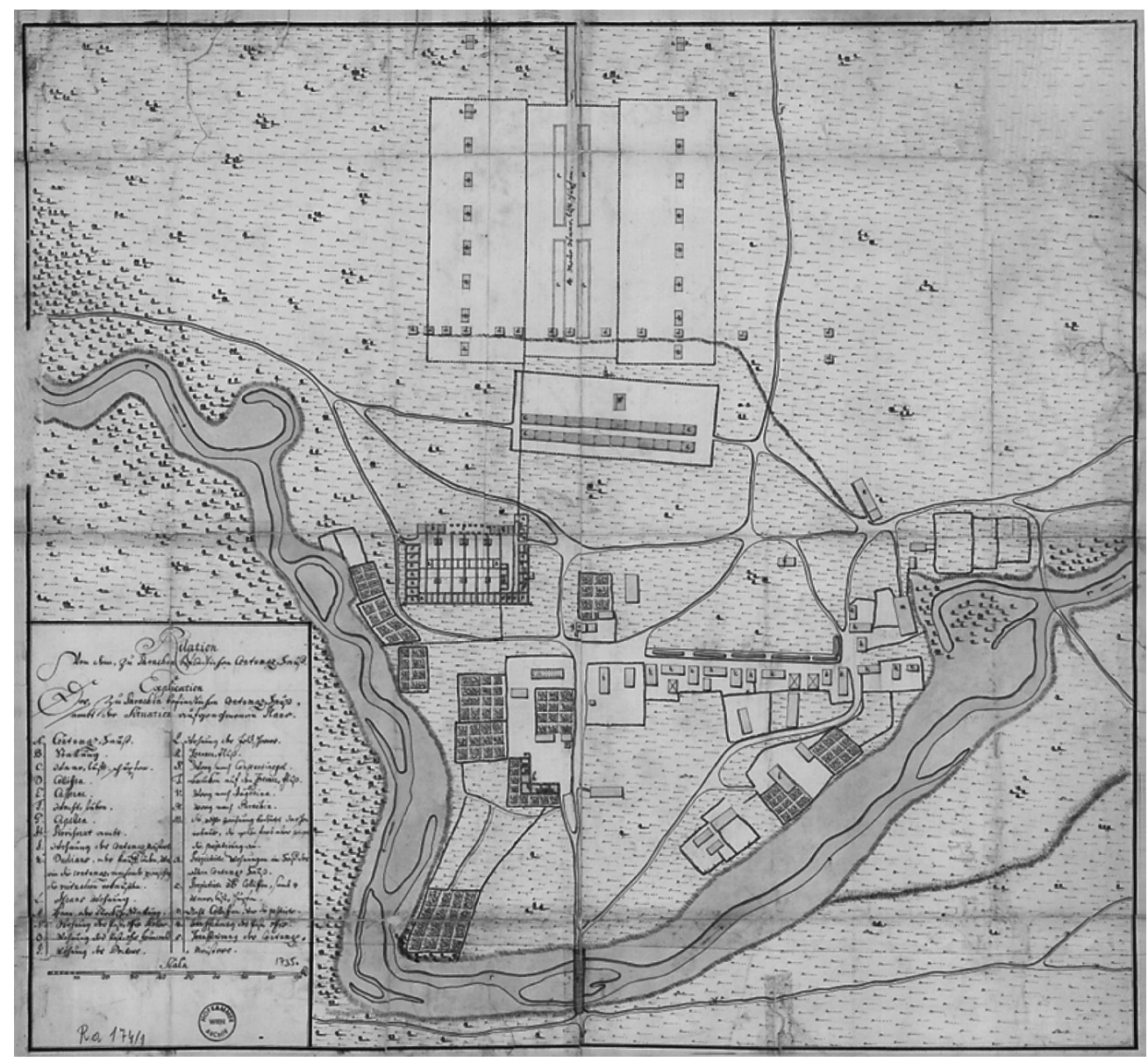

Fig. 2. Paraćin quarantine (War archive, Vienna, 1735) [18] 


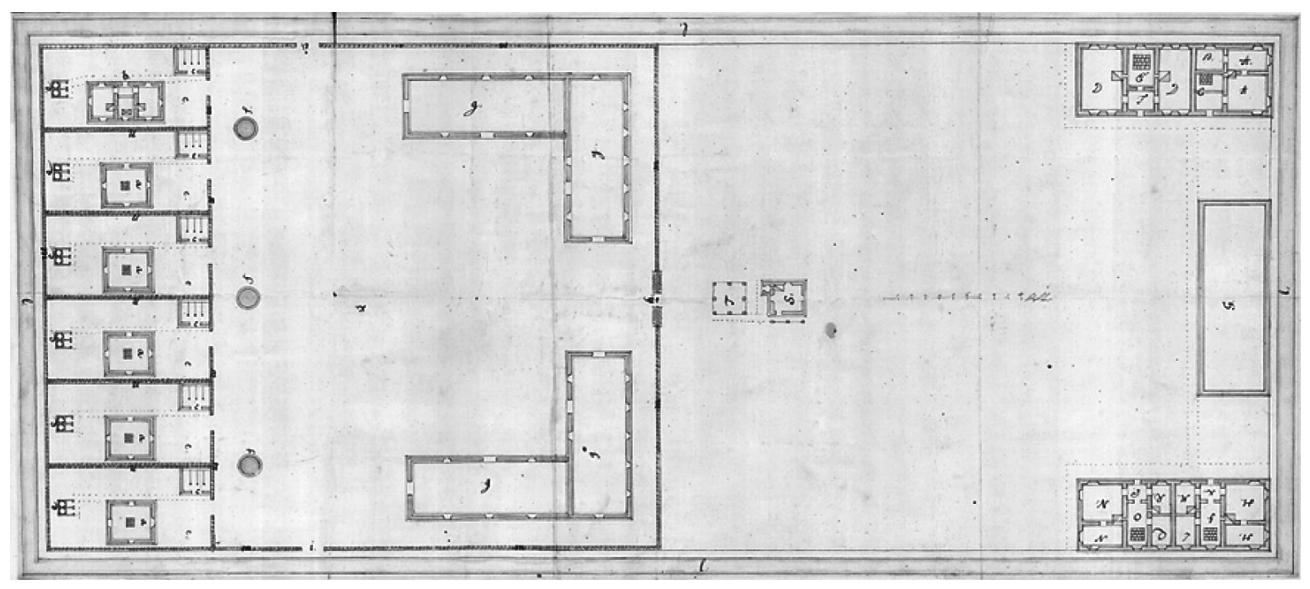

Fig. 3. Sketch of Prnjavor quarantine (War archive, Vienna, 1733) [19]

It should be emphasized straight away that quarantine personnel were living in separate rooms of quarantine building, which corresponds to state aspiration to save on providing housing for administrative personnel. Although these rooms were clearly divided from ones for inspection of goods, people, letters and animals, it often happened that someone from staff was infected, so they stayed all the time at the same quarantine to avoid spreading of infection. Keeping of infected persons in the quarantine was strictly forbidden, and it was responsibility of at least one physician or surgeon. If infected were from Ottoman Empire they were sent back straight away and goods were confiscated, but if it was someone from quarantine staff he was urgently taken to hospital, and new people were taken as replacements. Higher authority was informed instantly and their orders awaited, especially if quick spreading of infection was threatening. Servants and goods cleaners, employed exclusively for that purpose, were not allowed to have any contact with persons who were not members of quarantine staff [20].

When personal belongings of merchants and travellers were examined, procedure amounted to cleaning by clean air and sun. Namely, if not on rats fleas were dying at temperatures below 10 or above 40 degrees Celsius, in combination with air humidity below 70 percent. Even when conditions were favourable for development of Xenopsyllas, it was proved that within 38 days they die if not infected and fed. Infected fleas could survive overland transport if they were in fur or bales of wool or cotton [14 p81].

Crucial was the manner how bales of wool, flax and silk were treated. Taught by previous experiences, sanitary commission was sending stricter instructions regarding storing and keeping of fabrics, since unsupervised staff often slept on those bales thus increasing infection risk. Rough wool fabrics, fibre fabrics, cotton, silk, flaxen fabrics, muslin and fabrics from animal hair had to be in the open for six weeks, freed from packaging. It was estimated that three weeks in the open are enough only for most expensive silk. Those goods that was believed to be less susceptible to infections 
(fruits, coffee, rice, cereals, wooden and metal objects) were taken out of basket or bag they were transported in and left in the open three weeks and washed (cleaned). Wheat was often just sieved to separate from unwanted materials, paper, piece of wire and other risky materials where Xenopsyllas could hide. Bags in which goods were transported had to be washed with water several times, and those that were carrying infected goods were burnt [20].

Big danger in infection transfer were coins, for it changed many hands and could communicate disease from sweat of infected hands. Metal coins, coppers, silvers and gold coins were cleaned in vinegar or salty water. Safety standard was tightened in 1770, so coins were cleaned in boiling salty water, and in a case of epidemics in boiling vinegar solution. This was main reason that paper money issued by Vienna bank was rarely used [14 p83]. Finally, liquids like oils and balms had to be repackaged to cross the border [20].

Court sanitary commission in raised control level in 1726 by appointing duty physicians in quarantines of busiest checkpoints on border with Ottoman Empire. Appointing of one permanent physician and two surgeons (Hyer Schwendimann and Karl Oberleutner), as well as two commissars for informing on communicable diseases (Burkhard Koller and Franz Reuhard) [13, 21 p500], was done in order to keep all goods coming from Ottoman Empire at Paraćin quarantine until further notice, regardless if it was already quarantined or yet had to come. It should be observed that a result of that decision was absolute break of legal trade between two empires, although it was already declining due to low purchasing power of local population. On dangers from plague that was spreading towards Priština in 1727 was warning a commander of Austrian units stationed in Jagodina (Schnepper) [16 pp127].

Preservation of public health remained one of main issues for Court war council in the next year, so procedures were complemented with such measures as ban on import of food and fur, and maximizing quarantine time for other goods [22 p84]. Caution measures were strictly applied, so provisions for staff of quarantines situated by a river were delivered by ships that would not dock, but exchange of goods was performed at secure distance from river bank [13]. Due to withdrawal of Austrian army towards Belgrade during Austro-Turkish war in 1937, entire Paraćin quarantine with full staff was moved to Jagodina [13, 23 p111]. At that time came the last report sent to sanitary commission that mentioned Paraćin quarantine. Theplague reappeared in that year and ravaged large area populated by Serbs, having epicentre in Timisoara Banat and Kingdom of Serbia. By August 1738 quarantine was established in Pančevo, but after infection appeared within, it was moved for safety reasons [13].

The working concept of quarantines changed substantially in time, thanks to study of physicians' and surgeons' reports. With biopolitics definition by Michel Foucault as a starting point, Habsburg court built supervising mechanism in institutions controlling public health system to ensure durance of biopolitics in the Monarchy [24 p296]. The treatment of science changed gradually towards the end of 
century, so all over the state were carefully read published papers on functions, forms and efficiency of quarantines, medical reports of physicians and proposed methods for reforming quarantine enduring and modes of isolation. Expertise of Austrian physicians was often supported by personal experience gained during employment in quarantines or visits of almost 1,900 kilometres long border with Ottoman Empire. At the end of 18th century scientists were still not aware what causes plague, so most important role of quarantines was to break cycle of disease transfer. Although some progress was achieved regarding duration of quarantine, system of closing borders that started in 17th century was still applied. Such regime affected merchants, since withholding and long storing of goods at borders caused quality loss. Traditional perception of state measures for controlling plague persisted to beginning of 19th century, and that negatively affected economic development, primarily in southeast part of the Monarchy.

\section{Rezime}

Preduzimanje neophodnih mera kako bi se sprečilo širenje bolesti iz novoosvojenih habzburških provincija u 18 . veku pokazuje težnju države da preuzme kontrolu nad unutrašnjim rizicima od epidemije, kao i da se u vanrednim situacijama populacija periferije odvoji od ostatka monarhije. Stvaranjem nadzornog mehanizma u institucijama koje regulišu sistem javnog zdravlja, habzburški dvor je učvrstio trajnost biopolitike u monarhiji. U konceptu rada kontumaca vremenom je dolazilo do bitnih promena zahvaljujući praćenju izveštaja lekara i hirurga. Odnos prema nauci se postepeno menja do kraja veka, a u državi se sa velikom pažnjom čitaju publikovani radovi o funkcija, formama i efikasnosti kontumaca, zatim medicinski nalazi lekara, kao i predlozi za reformu metoda izdržavanja kontumaca i načina izolacije. Stručno znanje austrijskih lekara često je bilo podržano i ličnim iskustvima tokom službovanja i obilaska kontumaca duž skoro 1.900 kilometara duge granice prema Osmanskom carstvu. S obzirom na to da naučnici krajem 18. veka još uvek nisu bili svesni šta izaziva kugu, najvažnija funkcija kontumaca je bila da razbije ciklus prenošenja bolesti. Iako je bilo napretka kada se odlučivalo o smanjenju vremena izdržavanja kontumaca, sistem zatvaranja granica nastao još u 17. veku i dalje je primenjivan. Paraćinski kontumac bio je jedan od najvažnijih za austrijske vlasti, pre svega jer se nalazio na tzv. Carigradskom drumu. Postupak izdržavanja kontumaca najviše je pogađao trgovce, jer suočeni sa zadržavanjem i dugim skladištenjem njihove robe na granici, gubila je na kvalitetu i ceni. Sa austro-turskim ratom 1737-1739. kontumac se izmešta iz Paraćina kako se austrijska vojska povlačila na sever, a nakon Beogradskog mira tradicionalna shvatanja o sprovođenju državnih mera za kontrolu kuge još dugo je izazivalo negativne efekte na ekonomski razvoj pre svega u jugoistočnom delu monarhije.

\section{References}

1. Jesner S. The Physician Adam Chenot - Reshaping Plague Control in the Austrian Cordon Sanitaire (approx . 1770-1780). Banatica 2015;25:283-300.

2. Kocić M, Dajč H. Kuga u ranomodernom Beogradu: uzroci, strahovi i posledice [Plague in early modern Belgrade: causes, fears and consequences]. Acta hist med stom pharm med vet. 2014;33(1):152-161. 
3. Пешаљ Ј. Између врача и лекара: Обележја здравствене културе [Between medicine man and doctor: characteristics of health culture]. In: Фотић A, editor. Приватни живот у српским земљама у освит модерног доба. Београд: Клио 2005; 475-504.

4. Samaržija Z. Habsburško vojno zdravstvo u Slavoniji i Srijemu do ukidanja vojne krajine [Habsburg military healthcare in Slavonia and Syrmia up to the abolition of Military Frontier]. Acta hist med stom pharm med vet. 2013;32: 95-119.

5. Kallbrunner J. Deutsche Erschliessung des Südostens seit 1683. Jena: Diederichs; 1938.

6. Станојевић Г. Епидемија куге у Србији 1719. године и превентивне мјере у Венецији [Plague epidemic in Serbia in 1719 and preventive measures in Venice]. Српски архив за целокупно лекарство 1973;11-12: 937-942.

7. Sticker G. Abhandlungen aus der Seuchengeschichte und Seuchenlehre, Die Pest. Band I, Gießen: Verlag von Alfred Töpelmann; 1908-1910.

8. Horn E. Archiv für medizinische Erfahrung im Gebiete der praktischen Medizin, Chirurgie, Geburtshülfe und Staatsarzneikunde. Volume 56. Berlin: Reimer; 1829.

9. Briefe der Lady Marie Worthley Montague, während ihrer Reisen in Europa, Asia und Afrika, an Personen vom Stande, Gelehrte u. in verschiedenen Theilen von Europa geschrieben; welche außer anderen Merkwürdigkeiten Nachrichten von der Staatsverfassung und der Sitten der Türken enthalten. Leipzig: Weidmann; 1764.

10. Taschen-Bibliothek der wichtigsten und interessantesten Reisen in die Türkei ... Verfaßt von Mehren Gelehrten und hrsg. von Jäck J H, Vol. 2-3, Nürnberg: Haubenstricker u. Ebner; 1829.

11. Дивљановић Д. Прилог грађи за историју Ваљева и околине у доба аустријске окупације Србије од 1718-1739. године [Contributions to sources for the history of Valjevo and its surroundings at the time of the Austrian occupation of Serbia 1718-1739]. Гласник - Историјски архив у Ваљеву. 1967;2-3: 14-17.

12. Deutsche Biographische Enziklopädie (Hg. Rudolf Vierhaus). Nachträge/Personenregister. Band 11. München: K. G. Saur; 2008.

13. ÖeStA/KA ZSt MilKom Sanitätshofkommission Bücher 1.

14. Balazs P, Foley KL. The Austrian success of controlling plague int the 18th century: martime methods applied to continental circumstances. Journal of History of Culture, Science and medicine. 2010;1(1): 73-87.

15. Гавриловић В. Фрагменти прометног протокола контумаца у Параћину [Fragments of the transport protocol quarantine in Paraćin] (1723, 1731. и 1733), Мешовита Грађа. 2008;28: 73-80.

16. Митровић М. Подаци о Србији у протоколима Дворског ратног савета у Бечу [Data on Serbia in the protocols of the Court War Council in Vienna] (1717-1740). Београд: Споменик САНУ, том 130; 1988.

17. Linzbauer FX. Codex Sanitario-Medicinalis Hungariae. Tomus II. Budae: Typis Caksarko-Regiar ScientiarumUniversitatis; 1852-1856.

18. ÖeStA/FHKA SUS KS, Ra 0174/1, 2. Kontumazhaus in Parachin.

19. ÖeStA/FHKA SUS KS, Rb-589/1. Kontumazgebäude zu Bruniavar in Serbien.

20. ÖeStA/FHKA SUS Patente 63.7. (1731). 
21. Sammlung Oesterreichischer Gesetze und Ordnungen, Wie solche von Zeit zu Zeit ergangen und publiciret worden, So viele deren vom Jahr 1721 Biß auf Höchst- traurigen Tod-Fall Der Römisch-Kayserlichen Majestät Caroli VI. aufzubringen waren ... Wien: Johann Thomas Edlen von Trattnern; 1752.

22. Lesky E. Die österreichische Pestfront an der k. k. Militärgrenze. Saeculum. 1957;8; 82-106.

23. Пецињачки С. Подаци о куги 1738. године у Бечкереку, Дески и Ђали [Data about the plague of 1738 in Bečkerek, Deska and Đala]. Зборник МС за историју. 1975;11; 111-117.

24. Фуко М. Треба бранити друштво [Society must be defended]. Предавања на Колеж де Франсу из 1976. године, Нови Сад: Светови; 1998.

Submitted: 28. 11. 2016.

Reviewed: 5. 12. 2016.

Accepted: 10. 12. 2016. 